\title{
Nye læreskabeloner - nye lærerum tættere på og længere væk fra praksis
}

\begin{abstract}
Læringsbegrebet har været til debat i en årrække, og der er blevet stillet spørgsmålstegn ved såvel de kendte læringssammenhænge som ved forestillingerne om viden, som noget der kan opbevares og overføres. Hvordan dette hænger sammen med ændrede samfundsmæssige forhold, og hvilke ændringer dette fordrer for vores tænkning omkring nye læreskabeloner og lærerum diskuteres i artiklen.
\end{abstract}

\section{Nytænkning af lærebegrebet}

Vi har i 1990erne været vidne til opbrud og nytænkning med hensyn til, hvordan og hvor mennesker bedst lærer. Begrebet livslang læring (Fischer 1999) og forestillingerne om et nyt kompetencebaseret læringsbegreb (Kirschner 1999) er i dag blevet en del af vort almindelige ordforråd. Man taler om den konstruktivistiske drejning inden for forskning om uddannelse og læring med erkendelsen af, at viden ikke blot tilegnes, men aktivt konstrueres af den lærende på grundlag af dennes mentale og sociale beredskab (Elkjær 1999; Garrison 1995; Philips 1995). Læring gennem deltagelse i praksis og læring gennem mesterlære har tillige oplevet en renæssance i de senere år (Lave \& Wenger 1991; Nielsen \& Kvale (red.) 1999; Schön 1983 og 1987).

Det er ikke blot teorier om læring, der har ændret sig, men begrebet viden har ligeledes fået ny betydning. Viden kan såle- des ikke længere blot forstås som repræsentation, der nemt kan lagres i bøger, i hjerner, på CD-rom, diskette og på 'nettet'. Viden konstrueres af et individ eller en gruppe i tilknytning til en anvendelsessammenhæng - gennem problemformulering, løsning og refleksion. Viden anskues således inden for nyere sociale læringsteorier som et resultat af indre, kognitive processer hos den enkelte, samtidig med at viden skabes og trives i såkaldte praksisfællesskaber eller communities of practice. Der er ligeledes en større forståelse af, at viden ikke kan forblive inden for bestemte afgrænsede faggrupper, men at dens problemorienterede karakter fordrer krydsning af fagligheder.

Når disse teorier om læring og viden får en opblomstringsperiode nu, skyldes det for det første, at de kendte og anvendte 'læreskabeloner og lærerum' i dag er ved at have udspillet deres rolle. For det andet, at de samfundsmæssige vilkår har ændret sig og 
dermed også betingelserne for uddannelse og læring. Der er nemlig ikke så meget nyt i 'det nye' lærings- og vidensbegreb. Det nye er, at de samfundsmæssige vilkår har udviklet sig i en retning, der gør, at de traditionelle læreskabeloner og -rum må anfægtes. Det danske samfund er ikke længere baseret på industriproduktion, men på produktion af service, information og viden $\mathrm{i}$ en stadig mere krævende konkurrence på et globalt marked.

Vi ser i nytænkningen inden for uddannelse og læring et behov for at udvikle nye og eksperimenterende lærerum for igennem denne praksis at udvikle nye læreskabeloner. Konkret foreslår vi to organisationsformer - udviklingsorganisationen og læringslaboratoriet - som to eksperimenterende lærerum. Det førstnævnte lærerum er tilknyttet den enkelte virksomhed, og det sidstnævnte én eller flere uddannelsesinstitutioner. I begge lærerum er det muligt at eksperimentere med nye læreskabeloner relateret til praksis. I udviklingsorganisationen er man tæt på en konkret praksis - her eksperimenterer og lærer man med afsæt i det konkret levede arbejdsliv på en virksomhed. I læringslaboratoriet er det den lærendes autentiske udforskning og erfaringsdannelse, der er i centrum. Læringslaboratoriet erstatter den traditionelle undervisningssammenhængs fokus på metoder og værktøjer med mere åbne og kollaborative lærerum, der står distanceret fra den konventionelle praksis.

Vi præsenterer i det følgende dels en bevægelse væk fra industrisamfundets fokus på kvalifikationer og uddannelse, og dels baggrunden for, at videnssamfundet frembringer behovet for nye læreskabeloner og rum. Det er ikke længere relevant at tale om kvalifikationer som nogle mere eller mindre faste konstanter. I stedet handler det om at anskue kvalificering som tilegnelse af et beredskab til at definere og løse problemer samt reflektere over relationen mellem problemdefinition og problemløsning og konsekvenserne heraf. Dernæst introducerer vi begreberne læreskabelon og -rum på baggrund af en række empiriske forskningsresultater, der problematiserer lærings- og vidensbegrebet. Afslutningsvist udfolder vi de mulige læreskabeloner, der knytter sig til de to eksperimenterende lærerum, udviklingsorganisationen og læringslaboratoriet.

\section{Industrisamfundets Iæreskabeloner og lærerum}

Betegnelsen 'videns- eller informationssamfund' anvendes ofte for at indikere, at vi er på vej væk fra tidligere tiders landbrugsog industrisamfund. Videnssamfundet er karakteriseret ved, at flere og flere mennesker beskæftiger sig med data, informationer og viden, fordi de arbejder i ikke producerende servicevirksomheder. Denne udvikling skaber grobund for at tale om vidensintensive virksomheder og vidensarbejdere (Elkjær 2000) eller symbol-analytikere (Reich 1991). Vidensarbejdere er i stand til at definere og løse de uventede problemer, der måtte opstå i deres arbejdsmæssige praksis. De har desuden typisk et langt større overblik over helheden i deres arbejdsorganisation end industriarbejderen. En vidensintensiv virksomhed er således karakteriseret ved at udføre ikke-rutinemæssige opgaver, hvor vidensarbejdere beskæftiger sig med ikke-på-forhånd-kendte funktioner med opbud af al deres kreativitet (Alvesson 1995). Det kan f.eks. være specifikt kundetilpassede produkter eller servicefunktioner, hvor der følgelig skal ske en kontinuerlig omstilling af maskiner og tilrettelæggelse af nye servicefunktioner.

Når en samfundstype afløses af en an- 
den, ændrer kravene til kvalifikationer og uddannelse sig - om ikke på en gang, så som en udviklingstendens. Det er baggrunden for at hævde, at kvalificering i videnssamfundet mere handler om at udvikle et beredskab til at definere og løse problemer i praksissituationer samt at reflektere (læs: tænke) over sammenhængen mellem definitionen af problemet, handlingerne for at løse det og konsekvenserne heraf - og mindre om at tilegne sig en på forhånd fastlagt viden. Data og information er ingen knap ressource. I stedet drejer det sig om at være i stand til at skaffe sig de relevante informationer, så man i situationen kan konstruere den relevante viden. I videnssamfundet handler læring således om kontinuerligt at udvikle sine erfaringer (viden) i - og i relation til - arbejdet og hverdagslivet.

Industrisamfundets læreskabelon er baseret på industrisamfundets masseproducerende virksomheder og på forskning i industrisamfundets arbejdsprocesser. Her har forskere fulgt arbejdere med stabile arbejdsfunktioner og har på den baggrund været i stand til at udvikle en læreskabelon baseret på deres beskrivelser af arbejdsprocesserne. Det er en læreskabelon baseret på, at man i god tid har kunnet planlægge ændringer af arbejdsprocedurer og teknologier for så efterfølgende at tilrettelægge uddannelse med henblik på at skabe de nødvendige kvalifikationer hos medarbejderne. Selve kvalificeringen til at opnå kvalifikationerne er dernæst ofte tænkt ind i enten et kursusmiljø eller on-the-job træning, f.eks. gennem 'sidemandsoplæring' og tutor- eller mentorarrangementer. Disse lærerum er karakteriseret ved, at viden er blevet overført fra en mere vidende til en mindre vidende og af, at man som den mindre vidende har kunnet overføre viden fra læresituation til arbejdssituation.

Et eksempel på en kendt og anvendt læreskabelon er 'sidemandsoplæring'. 'Sidemandsoplæring' er karakteriseret ved at indeholde klare og faste forventninger til såvel den erfarne som nybegynderen. Som nybegynder - og sidemand - forventes man at gå til hånde samt at følge med $\mathrm{i}$, hvordan den erfarne udfører opgaverne for gradvist selv at overtage en større og større del af opgaverne. Logikken er, at hvis nybegynderen er god til at imitere og at spørge i tvivlssituationer, 'så går det nok'. Hvis vi dertil lægger, at forskellige typer af opgaver skal løses med kendte mellemrum, så er det til at forudsige, hvornår nybegynderen er en erfaren medarbejder. 'Sidemandsoplæringen' er et eksempel på en læreskabelon, der vil komme mere og mere under pres. Billedet af sidemanden som den, der imiterer indarbejdede rutiner, passer dårligt med, at opgaverne bliver mere varierede og vanskelige at forudsige.

'Sidemandsoplæringen' er som læreskabelon præget af, at man først har kunnet planlægge ændringer af arbejde, derefter ændringer af viden og kunnen. Man kan, inspireret af den canadiske medieforsker Marshall McLuhan (1964, c. 1994), sige, at industrisamfundets læreskabelon og -rum er præget af 'sekvenstænkning'. McLuhan taler om et skift fra den mekaniske til den elektroniske tidsalder og lægger vægt på, at de elektroniske medier sætter en anden dagsorden for vores omgang med viden. Hvis vi parallelliserer McLuhans begreb om den elektroniske tidsalder med begrebet videnssamfund, så siger McLuhan, at vi med overgangen til videnssamfundet forlader et vidensbegreb baseret på 'sekvenstænkning'. Dette vidensbegreb er karakteriseret ved, at viden først opbevares, siden kontrolleres og for derefter at blive transporteret, f.eks. som skrift på papir. I den nye tidsalder er al information og viden $\mathrm{i}$ princippet til stede overalt og samtidigt. 
Det er et vidensbegreb baseret på 'samtidighedstænkning'.

I McLuhans mekaniske tidsalder var eksperten ham eller hende, der f.eks. i opbygningen af en ny produktionslinie mestrede den omhyggelige planlægning og var i stand til at kontrollere anvendelsen af viden, når planerne skulle udføres. Eksperten i den elektroniske tidsalder er imidlertid en person, der ikke lader sig hæmme af kendte fremgangsmåder 'sådan plejer vi at gøre her'. Det er en person, der kan skabe orden ud af et virvar af informationer og viden samt konstruere ny og relevant viden. Det er ligeledes en person, der er i stand til at etablere de relevante faglige netværk og relationer, samt bruge dem i sin egen læreproces og videnskonstruktion. Udbredelsen af de elektroniske medier bringer således en 'samtidighedstænkning' i spil. 'Samtidighedstænkningen' må nødvendigvis afspejle sig i en revision af det hidtidigt dominerende lærings- og vidensbegreb.

I det følgende vil vi med udgangspunkt i empirisk forskning om læring pege på behovet for at eksperimentere med nye læreskabeloner og -rum. Vi lægger ud med at vise, hvorledes læring er situeret og finder sted på grundlag af deltagelse i praksisfællesskaber. Dernæst tematiserer vi relationen mellem praksis og teori - kommer teori før praksis, eller er det omvendt? Dette afsnit efterfølges af et afsnit om, hvorledes læring opstår i mødet mellem forskellige fagligheder. Vi afslutter denne del af artiklen med at argumentere for, at lærerum må indeholde muligheden for at reflektere i og over praksis for at resultere i et læringsudbytte.

\section{Situeret læring og viden}

Brydningen mellem læring som en afgrænset aktivitet og læring som en integreret del af f.eks. arbejdet, kan ses som en følge af de tilsvarende brydninger, der opstår i mødet mellem industrisamfundets 'sekvenstænkning' og informationskontrol og det gryende videnssamfunds tænkning i netværk og samtidighed. Hvor det $\mathrm{i}$ industrisamfundets optik er hensigtsmæssigt at tænke læring som noget, der går forud for og er afgrænset fra handling, så tilsiger videnssamfundets optik et fokus på samtidighed og integration af handling og læring. Disse brydninger og skift er voldsomme og gennemgribende og rækker givetvis mange årtier både fremad og bagud i tiden. Den ny dagsorden for læringsdiskussionen anfægter de konventioner og den fælles intuition, der har udviklet sig i de miljøer, som tager del i den pædagogiske debat.

Den aktuelle debat om læring rejser en række 'gamle' spørgsmål om læringens sociale og psykologiske dynamik. Vi vil hævde, at læringsproblematikken må eksponeres på nye måder. Læring forstået som en kontinuerlig og kontekstuel refleksionsproces trænger sig på i stadig større grad - i modsætning til læring som tilegnelse af færdigpakkede videnselementer. Det bliver stadig tydeligere, at læring er en social proces, der handler om at deltage i praksisfællesskaber. Den lærende må kontinuerligt pendle mellem praksis og teori, og læring fordrer, at der findes rum for refleksion. Læring - udvikling og ændring af mennesker - foregår i et samspil mellem den enkelte og de situationer, som han eller hun er en del af. Det er gennem dette samspil, at erfaringer bliver til (Dewey 1916, c. 1966); erfaringer som skaber det handleberedskab, der gør den enkelte i stand til kompetent at bevæge sig ind og ud - og på tværs - af forskellige sociale relationer, situationer og fagligheder.

Den amerikanske antropolog Jean Lave udførte i starten af 1980erne en større undersøgelse af, om der var en sammenhæng 
mellem voksne elevers matematikpræstationer $i$ et institutionaliseret undervisningsog læremiljø og deres evne til i øvrigt at arbejde med tal (Lave 1988). Lave fulgte en gruppe kvinder i deres daglige gøremål for i første omgang at identificere situationer, hvor kvinderne var udsat for hverdagslivets regneopgaver. Det var situationer, der rummede regneopgaver, der også indgik i grundskolens afgangsprøver. Det gjorde det muligt at sammenligne de situationer, hvori der indgik de samme regnefærdigheder i henholdsvis hverdagslivet og i skolelignende situationer. En typisk situation fra hverdagen var en indkøbstur i et supermarked, hvor kvinderne skulle beregne, hvad der var det mest fordelagtige tilbud inden for forskellige varegrupper.

Undersøgelsens resultater var overraskende, idet der ingen sammenhæng var mellem kvindernes regnefærdigheder i skolen eller i de skolelignende situationer og f.eks. i supermarkedet. En kvinde kunne være særdeles dygtig til regning i det institutionaliserede læremiljø, men direkte dårlig til det i supermarkedet - og omvendt. Undersøgelsen viste tillige, at kun et fåtal af kvinderne anvendte samme regnemetode $i$ de forskellige situationer.

Lave's konklusion var, at regnefærdigheder er betingede af situationen, hvori der skal regnes - eller med andre ord - at læring er situeret. Det betyder, at det ikke nytter at forbedre menneskers matematiske kundskaber i et institutionaliseret læremil$\mathrm{j} \varnothing$, hvis de har problemer med at udføre beregninger i arbejdslivets situationer. Udviklingen af regnefærdigheder må i stedet finde sted i korrespondance med de arbejdsrelaterede situationer, hvori de skal anvendes.

Læring i skolelignende situationer eksisterer naturligvis ikke kun som en forberedelse til praksis, idet denne form for læring ofte primært findes for at forberede til det næste trin i uddannelsesforløbet. Det anfægter imidlertid ikke det forhold, at der ingen forbindelse er mellem læring i en skolesituation og en anden anvendelsessituation. Det er således mere reglen end undtagelsen, at gymnasielærere brokker sig over, at elever fra folkeskolen ikke har lært nok, ligesom vi på de højere læreanstalter heller ikke synes, at de studerende har tilstrækkelige forkundskaber. De skjulte læreplaner (Bauer \& Borg 1976, c. 1986; Broady 1981; Rasmussen 1999) og de konkrete praksislogikker (Bourdieu 1990) er forskellige fra institution til institution - fra arbejdsplads til arbejdsplads. At det institutionaliserede undervisningsmiljø skaber socialisering til selve uddannelsessystemet er en del af spillets regler. Men det er lige så vigtigt at tænke på, at selve socialiseringen også er situeret og konstrueret i de konkrete praksisfællesskaber. Det uddyber vi i det følgende afsnit.

\section{Læring som deltagelse i praksisfællesskaber}

Læring og konstruktion af viden tilhører ikke udelukkende individet, men dannes og vedligeholdes på den enkelte institution og arbejdsplads $i$ et komplekst mønster, der ikke altid er gennemskueligt for den enkelte. Antropologen Julian Orr har f.eks. beskrevet, hvorledes en gruppe reparatører af kopimaskiner delte en stor fond af kollektiv viden (Orr 1996). Reparatørerne havde hvert sit distrikt, hvor de tilså og reparerede kopimaskiner. De arbejdede typisk alene og lærte med tiden de forskellige maskiner at kende. Da kunden sjældent kunne vente længe på at få udført en reparation, arbejdede de ofte under stort tidspres og måtte finde løsninger på stedet.

Selvom reparatørerne arbejdede alene påviste Orr, at de i høj grad udviklede deres 
praksis og viden i fællesskab. Når de mødtes, f.eks. til fælles frokostpauser, fortalte de hinanden historier om det reparatørarbejde, de havde udført og om de vanskelige maskiner, de havde repareret. Orr kalder disse historier for 'krigshistorier', fordi de minder om historier om tabte og vundne slag. Historierne var beretninger om, hvordan vanskelige problemer blev løst og om de forskellige maskiners helt egne personligheder, som reparatørerne måtte lære sig at omgås for at kunne reparere dem. For reparatør-novicerne var disse historier med til at definere, hvordan man skulle gebærde sig ude hos kunderne. Men ifølge Orr spillede beretningerne også en rolle for de rutinerede reparatører, fordi de var med til at vedligeholde dét univers af viden og færdigheder, hvori de bevægede sig. Orr kalder også historierne for et reservoir af kollektiv hukommelse, som hver enkelt bidrager til, men som i sin helhed rækker langt ud over den individuelle reparatør.

Etienne Wenger er en anden forsker, der har beskæftiget sig med, hvordan færdigheder og viden er knyttet til praksisfællesskaber (Lave \& Wenger 1991; Wenger 1998). For Wenger er færdigheder og viden heller ikke noget, man individuelt besidder, men noget, der befinder sig i praksisfællesskabet. Han har studeret sagsbehandlere i et forsikringsselskab og i denne gruppe var det, ifølge Wenger, ikke den individuelle viden om sagsbehandling, der afgjorde, hvordan sagerne blev behandlet. Sagerne blev afgjort gennem deltagelse i gruppens stadige forhandlinger om dem. Deltagelse $\mathrm{i}$ disse forhandlinger var afgørende for, om man var en kompetent sagsbehandler. Gruppen var for Wenger et praksisfællesskab, hvori det kontinuerligt blev forhandlet og genforhandlet, hvad der var acceptabelt og nødvendigt i hver enkelt sag. Gruppen udviklede og modificerede løbende en række fælles forståelser, som hver enkelt sag blev holdt op imod.

For en ny sagsbehandler var det afgørende, at man blev lukket ind i dette praksisfællesskab, så man kunne deltage i disse forhandlinger. Deltagelsen for nybegynderen var mere perifer end for den rutinerede sagsbehandler. Men det er en vigtig pointe hos Wenger, at deltagelsen i forhandlingerne om sagerne heller ikke kunne undværes for den rutinerede sagsbehandler. Det var nødvendigt hele tiden at drøfte sagsbehandlingen - ikke blot med kollegaerne, men også med f.eks. klienten og andre berørte. I det veletablerede praksisfællesskab var der derfor ikke enkelte, der kunne peges ud som særligt kompetente. Det var nettet af relationer mellem deltagere, som var den egentlige kilde til gruppens færdigheder og viden.

Wenger går så langt som til at sige, at læring er deltagelse. Det betyder, at kompetent handlen $\mathrm{i}$ en bestemt situation altid er knyttet sammen med visheden om, at handlingen er acceptabel inden for den gruppe, man tilhører - samt at denne accept kun kan sikres ved hele tiden at tage del i gruppens aktiviteter. Hvis man ikke som ny sagsbehandler blev accepteret som deltager, når man begyndte sit arbejde, ville man ifølge Wenger ikke være i stand til at udføre sagsbehandlingen. Kom man omvendt ind i varmen, ville man hurtigt få adgang til den måde at håndtere sager på, som gruppen havde opbygget over længere tid. Man lærte på denne måde - gennem deltagelse i praksisfællesskabet - hvad kompetent sagsbehandling var i f.eks. et forsikringsselskab.

De ovennævnte forskeres påvisning af læring og viden som situeret og funderet i praksisfællesskaber tematiserer ikke eksplicit betydningen af relationen mellem praksis og teori. Vi får en implicit forståelse af, 
at praksis er det væsentligste, men ingen pejlinger i forhold til teoriers og begrebers betydning for læreprocesser og videnskonstruktion. Det råder vi bod på i det næste afsnit.

\section{Forholdet mellem praksis og teori i læreprocessen}

Normalt rangerer teori og boglig viden over praksisviden. Det betyder, at rigtig ekspertviden er den, der kan udtrykkes i teorier eller komplicerede regler. I en lang periode har der f.eks. været arbejdet på at skabe computer-baserede ekspertsystemer, hvor udviklere har forsøgt at begribe ekspertens kropsligt forankrede rutiner for at beskrive dem som regler for computeren. I midten af 1980erne udgav brødrene Dreyfus bogen Mind over Machine, hvor de gør op med denne tankegang (Dreyfus \& Dreyfus 1991). Dreyfus \& Dreyfus argumenterer, at klassisk ekspertviden hos f.eks. læger er blevet en del af deres selvforståelse og identitet på linie med f.eks. barnets viden om at cykle. Ekspertviden bygger på en langt mere kompleks genkendelse af mønstre, end noget computerprogram nogensinde vil være i stand til at eftergøre.

Dreyfus brødrene afviser ikke, at det er muligt, at formulerede regler eller nedskrevne instruktioner kan være en hjælp til at blive ekspert. Med bilkørsel som eksempel hævder de, at den nye bilist kan have gavn af regler som f.eks., at man bør skifte fra andet til tredje gear, når man opnår en bestemt hastighed. De beskriver, hvordan køreskoleeleven i en periode vil tænke intenst på denne regel og bruge den som en slags løftestang for overhovedet at bevæge sig på vejen. På et tidspunkt vil den nye bilist imidlertid opnå tilstrækkelig rutine, så de skifter gear efter motorlyden i stedet for efter en firkantet regel om at skifte gear, når man kører eksempelvis $30 \mathrm{~km}$ i timen.

Dreyfus brødrene arbejder med fem mentale trin på vejen fra novice til ekspert, og ét af deres kontroversielle synspunkter er, at de regler, der er nyttige på et tidligt trin for novicen, ikke blot bliver overflødige, men direkte uhensigtsmæssige på et senere trin. Med gearskifte eksemplet hævder de, at en endnu-ikke-rutineret-bilist ind imellem kommer til at tænke på reglen om at skifte gear ved en bestemt fart. Dette tankenedslag kan medføre, at bilisten overhovedet ikke kan finde ud af at skifte gear.

Udviklere af ekspertsystemer har arbejdet på grundlag af, at det er muligt at beskrive alle former for viden. Logikken har lydt:

at hvis bare vi-som eksperter og laerere - er dygtige nok til at beskrive, hvad man skal gøre for at blive ekspert på sit felt, så kan man lave systemer til at erstatte f.eks. lager, ingeniфrer og andre former for eksperter og ekspertviden.

Det er denne logik, Dreyfus brødrene har $\emptyset$ nsket at fremhæve i deres forskning samtidig med, at de ville tage et opgør med den. Dreyfus brødrenes forskning kan bruges til at problematisere læremulighederne ved f.eks. 'sidemandsoplæring', fordi den erfarne og nybegynderen i deres optik simpelthen vil benytte og have brug for helt forskellige måder at engagere sig i opgaven. Lidt firkantet sagt, så leverer de to brødre et godt argument for en praksisbaseret undervisning og en lærerrolle, hvor læreren bevidst arbejder med forskellene på sin egen og elevernes behov for regler og forklaringer.

Spørgsmålet er imidlertid, om Dreyfus \& Dreyfus tager tilstrækkeligt radikalt fat på læringsproblematikken. De synes ikke at 
tvivle på, at vi først engagerer os med hovedet, det vil sige teoretisk, førend vi kaster os ind i opgaven i praksis. Det er der for så vidt ikke noget mærkeligt $i$, fordi de som så mange andre først og fremmest fokuserer på, hvordan det skal lykkes for nybegynderen at trænge ind $i$ et nyt og ukendt vidensfelt. Alligevel er det værd at overveje, om selve tankegangen - at teori eller regler kommer før udforskning og indlevelse i praksis - er forkert. Et eksempel hentet fra en ingeniørskole kan give et fingerpeg om, at problemerne stikker dybere.

For maskiningeniører er den gren af fysikken, der kaldes 'mekanik', traditionelt betragtet som ét af de vigtigste grundfag, som de fleste ingeniørstuderende lærer i de første år af deres uddannelse. I 'mekanik' beskæftiger man sig med, hvordan kræfter virker og overføres mellem legemer i bevægelse, og hvordan f.eks. stive konstruktioner kan belastes. Der har længe været ført en diskussion blandt lærere på ingeniørskolerne om, hvordan grundfag som 'mekanik' skal indgå i studieplanen og specielt om, hvordan grundfagene kobles til de mere anvendelsesorienterede fag. Ved Massachusetts Institute of Technology (MIT), der af mange betragtes som én af de førende ingeniørskoler, og hvor adgangskravene er meget høje, udførte Crispin Miller en række pædagogiske eksperimenter i forbindelse med 'mekanik' undervisningen (Miller 1995). Miller tilrettelagde øvelser, der nøje svarede til de opgaver, de studerende havde lært at løse som traditionelle skrivebordsopgaver i 'mekanik' undervisningen. En typisk opgave var at konstruere en løfteanordning, der ved hjælp af en legetøjsmotor kunne løfte et $1 \mathrm{~kg}$ lod og holde det i en højde på en meter. Til at løse opgaven blev de studerende udstyret med konstruktionsmaterialer og en enkel værktøjskasse.

I sin afrapportering af eksperimenterne fremhæver Miller tre overraskende forhold ved den måde, de studerende arbejdede med konstruktionerne. For det første viste det sig, at de studerende kun i meget begrænset omfang benyttede sig af de teoretiske begreber om 'mekanik', de burde have tilegnet sig igennem skrivebords $\varnothing v e l s e r n e$. Hvis de studerende inddrog teoretisk viden, var det ofte kun sporadisk og med et fejlagtigt resultat. Det andet overraskende forhold var, at de studerende i deres arbejde med konstruktionerne i høj grad efterlignede konstruktioner, de tidligere havde set. Det resulterede i adskillige taljearrangementer, der overhovedet ikke fungerede. De studerende reproducerede den visuelle udformning, men kunne ikke få greb om, hvad der får taljearrangementer til at virke. Det tredje forhold, som peger på et komplekst samspil mellem teori og praksis, var de studerendes valg af fremgangsmåde i deres arbejde med taljekonstruktionerne. Det lykkedes nemlig for så godt som alle grupperne at konstruere det krævede løftearrangement. De studerende begyndte ikke med indgående overvejelser over, hvad der kunne være en løsning på opgaven. De gik i stedet meget hurtigt i gang med at eksperimentere med de udleverede materialer. De så, følte og mærkede på motor og byggematerialer og begyndte hurtigt at bygge noget, som så rigtigt ud, men som ikke opfyldte kravene til et taljearrangement. Men i takt med at de studerende opdagede dette, bragte de gradvist nye løsninger på banen. Det var således i mindre grad det formfuldendte udspil, men den kvalificerede evaluering af de forskellige løsninger, der drev de studerende frem mod målet.

Eksemplet med konstruktionen af taljearrangementer illustrerer på forbilledlig vis, at en læreproces ikke først begynder med begreber og teori efterfulgt af afprøvning heraf. I stedet foregår læreprocessen 
som en pendlen mellem idé, eksperiment og evaluering - ganske som Dewey allerede påpegede for mere end 100 år siden (Dewey 1916, c. 1966). Abstrakte begreber og sammenhænge spiller en rolle i læreprocessen, men først og fremmest som konkrete værktøjer, der indgår i et samspil mellem udspil til en mulig løsning på et problem og efterfølgende overvejelse af om løsningen fejlede eller virkede. I det følgende problematiserer vi også relationen mellem teori og praksis ud fra en påstand om, at begrebsanvendelse under alle omstændigheder er specifik. Når forskellige fagfolk mødes om at samarbejde, opstår der således helt nye fagligheder, nye begreber - ny praksis.

\section{Læring i mødet mellem forskellige fagligheder}

Udviklingen indenfor design af informationssystemer er et godt eksempel på, hvordan ny viden og nye fagligheder bliver til. Over de sidste tyve år har eksempelvis systemudvikling gennemgået en hastig udvikling fra at være et arbejdsfelt for dataloger med baggrund i tekniske edb kundskaber til at blive et tværfagligt felt, hvor nye informationssystemer udvikles $i$ et samarbejde mellem brugere, systemudviklere og programmører. Da brugerne for første gang kom ind i udviklernes univers i forbindelse med udviklingen af store edb-systemer til f.eks. banker og forsikringsselskaber, var det en udbredt opfattelse, at udviklere og brugere måtte mødes om at udveksle $\varnothing$ nsker til og indsigter i dét arbejde, som ville blive ændret med de nye informationssystemer. Ret hurtigt blev det imidlertid klart, at disse $\emptyset$ nsker og indsigter ikke blot kunne aftappes som eksisterende viden, men at forestillingerne om det nye system først bliver skabt i mødet med og samspillet mellem de forskellige involverede grupper.

Forskere indenfor systemudviklingsområdet taler således om, at det innovative design opstår i konfrontationen mellem forskellige fagligheder, forskellige praksisfællesskaber. De enkelte grupper møder op i udviklingsprojektet med hver deres standardforestillinger om gængse løsninger, men først i dét øjeblik, hvor de skal få disse standardløsninger til at hænge sammen, opstår muligheden for at lære noget nyt om såvel problemer som løsninger. Nogle er gået så langt som til at tale om design og innovation som et resultat af gensidige læreprocesser. Såvel brugerne som de forskellige udviklergrupper må således udfordres på deres etablerede viden, hvis de skal forny sig (Ehn 1987).

I den lille skala kan det samme mønster ses i det mere hverdagsnære møde mellem fagfolk. For nogle år siden blev der f.eks. lavet en detaljeret undersøgelse af, hvordan en lille gruppe maskinarbejdere lærte at udføre opstillinger på komplekse automater (Meier 1998). Baggrunden for undersøgelsen var en betydelig indsats på den pågældende arbejdsplads for at tage hånd om oplæringen af nye medarbejdere. Én af de nye maskinarbejdere i undersøgelsen var eksempelvis en rutineret maskinarbejder fra en anden virksomhed. Han blev sat sammen med en jævnaldrende kollega med mange års erfaring fra den pågældende arbejdsplads. Begge var i starten af 50erne, og den nye havde tidligere arbejdet som opstiller af en anden type produktionsanlæg.

Den hjemmevante opstiller forsøgte at få den nye mand til at indgå i en traditionel 'sidemandsoplæring', fordi virksomheden havde fokuseret så meget på oplæringssituationen. Han gjorde sig meget umage for at forklare, hvordan opstillingsarbejdet skulle gribes an, og han foreslog den nye at 
følge hans instruktioner. For den nye fungerede det tydeligvis ikke at blive bragt $\mathrm{i}$ en sådan situation. Hver gang den hjemmevante fortalte om, hvordan en bestemt automat opførte sig, svarede den nye ved at fortælle, hvordan han havde oplevet »præcis det samme« en gang, hvor han havde stået ved en helt anden type anlæg. Når den hjemmevante viste den nye, hvordan han udførte en bestemt opgave, svarede den nye ofte med bud på, hvordan det kunne gøres anderledes.

Essensen i de to fagfolks ganske mislykkede dialog viser en oplæringssituation, hvor to fagfæller med den samme uddannelse mødes med hver deres praksiserfaringer. Situationen illustrerer en læreskabelon, hvor den ene definerer sig som ekspert og samtidigt definerer den anden som novice. Det protesterer novicen over - han har samme uddannelse og har også gjort sig relevante praksiserfaringer. Han ønsker på ingen måde at indgå i den anvendte læreskabelons tildeling af elev- og lærerrolle.

Uddannelsessystemerne bestemmer ikke, hvordan deres elever, studerende og kursister siden kommer til at arbejde, men de er indflydelsesrige leverandører af læreskabeloner, som dette eksempel viser. Den hjemmevante påtog sig den typiske lærerrolle som den, der skulle levere viden og indsigter til eleven. Denne læreskabelon kræver imidlertid, at eleven accepterer sin rolle som elev - og dermed perifer. Det gjorde den nye ikke i denne situation, idet han ikke betragtede sig selv som nybegynder inden for opstilling af maskiner, og han ønskede heller ikke, at andre skulle se på ham som novice. Den nye $\varnothing$ nskede derimod med sine egne historier at legitimere optagelsen i sit nye arbejdsfællesskab. Omvendt ønskede den hjemmevante at positionere sig som den erfarne lærer ved at fastholde, at han havde de bedste og rigtigste fortællinger.
Vi har været rundt om den situerede læring, der finder sted som deltagelse i praksisfællesskaber. Vi har problematiseret den sekventielle adskillelse mellem teori og praksis, og hvordan ny viden kun kan opstå i det ligeværdige møde mellem forskellige faggrupper og inden for grupper af fagfæller med forskellige praksiserfaringer. Under disse problematiseringer ligger vores påstand om, at videnssamfundets potentielle 'samtidighedstænkning' fordrer nye læreskabeloner, der kræver eksperimenter i andre typer af lærerum. Disse lærerum, udviklingsorganisationen og læringslaboratoriet, er begge 'rum for refleksion'. Baggrunden for vores fremhævelse af refleksionens nødvendighed i læreprocesser og videnskonstruktion er temaet for næste afsnit.

\section{Rum for refleksion}

For nogle år siden gennemførte et AMUcenter et fors $\emptyset \mathrm{g}$ med at lægge et lodde-kursus ud på den arbejdsplads, hvor kursisterne arbejdede. I stedet for at gennemføre traditionelle lektioner og øvelser fik kursisterne stillet et særligt område til rådighed på virksomheden, hvor de havde tilgang til det relevante udstyr. Det var en række videoer med instruktioner og øvelser, som de samarbejdede om at komme igennem. Kursisterne havde desuden tilbud om lærerkontakt via telefon og fax. Ved evalueringen fandt såvel kursister som AMU-centeret, at forløbet havde været markant bedre end på et konventionelt kursus. Deltagerne havde opnået et godt og meget ens greb om det faglige indhold, og de var tilfredse med de praktiske rammer. Forbindelsen til læreren var nok blevet anvendt, men spillede tilsyneladende ikke nogen større rolle for forløbets succes.

Gevinsten ved at fjerne læreren var, at kursisterne dermed for alvor selv måtte ar- 
bejde med deres egne læreprocesser og selv skaffe sig nye færdigheder. Selve lærerummet var imidlertid ikke ligegyldigt. Det var af afgørende betydning, at materialerne og opgaverne var tilrettelagt med henblik på at give kursisterne en reference at forholde sig til. Vi tror dog, at det allervigtigste var, at kursisterne her i langt højere grad end i konventionelle læreforløb selv havde kontrol over den rytme, hvori de arbejdede og lærte. De havde kontrollen med deres eget lærerum, hvori de selv kunne vælge, hvordan de ville omgås værktøjer og andre hjælpemidler. Kursisterne var så at sige undsluppet den stive læreskabelon, som et skoleophold - på trods af enhver behjertet indsats - næsten uundgåeligt er i kraft af de uvante omgivelser, hvor man er uden sine egne ting og ikke selv kan bestemme over sin tid.

En arbejdsplads er et kendt, men ikke nødvendigvis et godt lærerum. I et projekt, hvor vi fremstillede en serie instruktionsvideoer beregnet til at støtte den interne oplæring, arbejdede vi en længere periode med en gruppe rutinerede maskinopstillere. Vi ønskede at dokumentere, hvordan en bestemt type opstillinger bedst kunne gennemføres (Binder 1998). I gruppen indgik et mindre antal opstillere fra den samme virksomhed. De havde i en årrække arbejdet med den type opgave, vi ønskede at filme. Til vores - og i nogen grad også til deres egen overraskelse - opdagede vi, at de forskellige maskinopstillere greb opstillingsarbejdet meget forskelligt an. Ikke alene valgte de ofte forskellige fremgangsmåder, de havde også hver især udviklet helt forskellige løsninger på den samme slags problemer og kunne $i$ en del tilfælde end ikke arbejde videre på hinandens opstillinger.

Produktionsopgaverne blev naturligvis løst, men tidsforbruget varierede ofte meget fra opstiller til opstiller, og der var ikke nogen naturlige anledninger til at lære af hinanden. For at forstå eksemplet er det vigtigt at vide, at der var tale om endog meget vanskelige opstillinger, som ingen uden for fabrikken vidste, hvordan man skulle håndtere. Der var altså ikke noget sted, hvor man kunne læse om, hvordan opstillingen skulle laves, eller nogle personer at gå til, som ville have svar på rede hånd. Man kan sammenligne eksemplet med eksempler fra procesindustrien, hvor det ganske mange steder er velkendt, at man ude i anlægget kan høre, at ét vagtskifte tager over fra et andet. Ventiler bliver stillet og pumper bliver startet eller stoppet, fordi det nye skift har deres idé om, hvordan anlægget bedst kører (Perby 1995; Zuboff 1988). Hvis man begynder at diktere, hvordan et kompetent hold af procesoperatører skal køre deres anlæg, er det det samme som at overtage ansvaret for driften. Det er der ikke mange andre end procesoperatørerne selv, der er villige til.

Hvad gør det kollegiale fællesskab mellem maskinopstillere eller afleveringsforretningen mellem to operatørskift anderledes end dét lærerum, lodde-damerne etablerede omkring deres AMU-kursus? Det er først og fremmest, at sidstnævnte situation er defineret som en læresituation - de førstnævnte situationer er 'bare' almindelige arbejdssituationer. Maskinopstillere og procesoperatører befinder sig nok i de kendte omgivelser, hvor de har såvel problemer som løsninger ved hånden, men når f.eks. maskinopstilleren skal overtage en opgave fra en kollega, så vælger han at lave opstillingen forfra. Dermed er han på sikker grund, og han får sjældent muligheden for at træde et skridt tilbage og overveje, hvad han eventuelt kunne lære af forskellene mellem, hvordan han og kollegaen arbejder.

Donald Schön var en amerikansk forsker, 
der i mange år beskæftigede sig med, hvordan forskellige grupper af professionelle som f.eks. musikere, læger og arkitekter lærer nybegyndere at håndtere professionens praksis (Schön 1987). Schön påviste, at den lærende person må befinde sig i et 'refleksivt praksisrum' (engelsk: reflective practicum). Det karakteristiske ved et sådant rum er, at det ligner den rigtige praksis så meget, at man kan arbejde på en professionel måde med autentiske problemer, men at det også er muligt at eksperimentere med forskellige problemløsninger vel vidende, at der er tale om en læreproces. Når det refleksive praksisrum ikke er et rigtigt arbejde, giver det en frihed til ikke blot at eksperimentere, men også til at reflektere over de problemer og løsninger, man arbejder med. Denne frihed er ifølge Schön en afgørende forudsætning for, at man kan lære at se problemerne på en ny måde.

Schön arbejdede selv meget med arkitekter og arkitektstuderende, og han var især optaget af dét paradoks, at arkitekten må lære sig sin egen, helt personlige måde at arbejde på, samtidig med at hun eller han som studerende må tilegne sig færdigheder, der gør arkitekten til medlem af en særlig faggruppe. Schön forskede i, hvordan de arkitektstuderende allerede fra den første dag i deres uddannelse arbejdede med autentiske arkitektopgaver, og hvordan de studerende blev hjulpet på vej af lærere, der ikke kunne vise dem, hvad de skulle gøre, men nok kunne forsøge at åbne deres øjne for nye veje ind i opgaven. Schön fandt, at lærere og studerende stort set aldrig forstod hinanden i den forstand, at de oplevede at have kendskab til hinandens tankegang. Derimod kunne de i fællesskab benytte, hvad han kaldte 'refleksions-stigen', hvor studerende og lærer - og studerende indbyrdes - på skift overvejede hinandens udspil $i$ arbejdet med opgaven, mens de be- vægede sig fra de konkrete til de mere abstrakte niveauer opad refleksionsstigen ved at dele reaktionerne på hinandens reaktioner.

Arkitekten er ikke noget dårligt forbillede for andre faggrupper, der også i stigende grad må lære, at hver opgave er ny og kræver et personligt engagement. Maskinopstilleren eller procesoperatøren er ikke blevet oplært så nænsomt som arkitekten, men lærer sig alligevel at udvikle sit specielle greb om opgaven. En stor udenlandsk fjeder-koncern begyndte f.eks. i starten af 1990erne at indføre halvårlige seminarer for deres opstillere. Her mødtes opstillere fra forskellige fabrikker og medbragte egne videooptagelser af opstillinger, som de på den ene eller anden måde fandt særligt interessante at diskutere med deres kollegaer. Derved skabte de en art refleksivt praksisrum. Forudsætningerne for at skabe sådanne refleksive praksisrum og rammer for læring er til stede på såvel arbejdspladsen som $\mathrm{i}$ de institutionaliserede uddannelsesmiljøer, hvis man er villig til at erkende, at de lærende selv må have kontrol over læreprocessen i såvel tid som rum.

I det følgende giver vi to eksempler på lærerum, hvori vi forestiller os, at man kan eksperimentere med nye læreskabeloner. Begge lærerum er refleksive praksisrum eller problemorienterede eksperimentarier. De er begge fleksible lærerum, som man kan gå ind og ud af - fysisk eller virtuelt og hvori der kan foregå erfaringsudveksling og vidensdeling på tværs af elev-og lærerroller. Det er autentiske erfaringer, der er grundlag for refleksionen. Der er altid mere end én løsning, og viden skabes kollektivt og på tværs af fagligheder.

Læreskabelonerne rummer først og fremmest muligheden for refleksion hjulpet af simulering, netværksdannelse, rollespil, video, o.s.v. 'Samtidighedstænkning' er i 
højsædet på baggrund af autentiske og virkelighedsnære problemer på tværs af praksis og teori og faglige fællesskaber. Det handler ikke først og fremmest om at tilegne sig en bestemt kvalifikation, men et beredskab til at definere og løse relevante problemer og reflektere over sammenhængen mellem definitionen og løsningen.

\section{Udviklingsorganisationen og læringslaboratoriet}

Problemerne med de kendte læreskabeloner og -rum har længe været genstand for opmærksomhed, men bestræbelserne på at indføre andre former så som gruppe- og projektarbejde støder på vanskeligheder, hvis de ikke umiddelbart lader sig oversætte til virksomme læreskabeloner $\mathrm{i}$ arbejdssammenhænge. Behovet for at gøre op med de kendte læreskabeloner og -rum rejser imidlertid en række spørgsmål til, hvordan læring og konstruktion af viden kan gribes an på en anden måde. Det er (nu som før) på én og samme tid en meget personlig proces at lære sig nyt, og en proces der er afhængig af de sociale rum og relationer, man har adgang til at udfolde sig i. Læreprocessen er intimt forbundet med mulighederne for at engagere sig - for at eksperimentere, erfare og skabe mening ud af dette engagement. Det er ikke tilstrækkeligt at se på læringens psykologi. De gode læreskabeloner og -rum findes i skæringen mellem det eksistentielt udfordrende og det socialt produktive.

Vi foreslår, at man kan eksperimentere med nye læreskabeloner i mindst to lærerum. Vi har kaldt det ene for udviklingsorganisationen, mens det andet kaldes læringslaboratoriet. De nævnte scenarier har afsæt i hver sin del af det traditionelle rum for arbejde og læring - arbejdsorganisationen og uddannelsesinstitutionen. Formålet er at skabe rum for at eksperimentere med disse to læremiljøer, og at udvikle nye læreskabeloner og nye modeller for selve arbejdet.

Formålet med udviklingsorganisationen er at skabe et lærerum, en permanent parallelorganisation, hvor man kan reflektere tæt på den arbejdsmæssige praksis (se også Engelstad 1996; Hvenegaard \& Trolle 1996). Man kan her ved i fællesskab at arbejde med problemdefinitioner og -løsninger i tæt tilknytning til virksomhedens praksis lære sig refleksionens kunst og dermed udvikle et handleberedskab til at blive en stadig mere kompetent medarbejder. Hensigten er således af skabe muligheder for udvikling af refleksive praksisrum, der er forbundet med den virksomhedsspecifikke praksis, og hvori deltagerne kan løse problemer samt i fællesskab reflektere og ræsonnere i snæver tilknytning til denne praksis. Konkret kan man f.eks. arbejde på innovationer af nye produkter og serviceydelser, nye ledelsesog samarbejdsformer, men også mere jordnære forhold som at udføre arbejdet mere hensigtsmæssigt kan være centrale i læreprocesserne.

Udviklingsorganisationen er afhængig af, hvilke erfaringer der findes i virksomheden. Både individer og organisationer har en historie, en nutid og (forestillingen om) en fremtid. Det er erfaringer, der må tages med ind i billedet, når udviklingsorganisationen skal materialisere sig. Organisationens samlede erfaringer er med til at bestemme, hvad der overhovedet kan ske i en virksomhed. Det er disse erfaringer, der bestemmer, hvilke forhold man kan rette sin opmærksomhed imod og hvilke løsninger, der kan foreslås. Udviklingsorganisationen giver tid og rum til at eksperimentere, så der kan arbejdes med konkrete udspil og overvejelser, samt med refleksionsstigens pendlen mellem det konkrete og det ab- 
strakte. Udviklingsorganisationen er en måde at skabe et eksperimentalt rum i og relateret til arbejdsorganisationen, men stadig i en struktur, hvor det er muligt at gå uden for de eksisterende organisatoriske konventionelle måder at gøre arbejdet. Det er en måde at skabe en læreskabelon og et læremiljø, der er tæt sammenvævet med arbejdsorganisationen, men som alligevel er eksperimenterende.

Udviklingsorganisationen kræver aktiv deltagelse og engagement af alle i en virksomhed. Det betyder, at man tager hensyn til, at forskellige grupper af ansatte $i$ en virksomhed har adgang til forskellige organisatoriske erfaringer og som sådan kan fremsætte problemer og løsninger fra disse forskellige positioner. Det er således ikke tilstrækkeligt at tage et par repræsentanter ud og så lære dem at tænke og handle på nye måder. Udviklingsorganisationen må aktivt involvere alle forskellige personlige og faglige erfaringer.

Læringslaboratoriet er en betegnelse for et læremiljø, hvor det er muligt at reflektere lidt længere væk fra praksis. Læringslaboratoriet er også et sted, hvor det er muligt at eksperimentere med forskellige læreskabeloner, men hvor udviklingsorganisationen trives i snæver tilknytning til de konkrete virksomheder, så knytter læringslaboratoriet an til f.eks. de lokale uddannelsesinstitutioner. Hensigten er dog den samme, nemlig at skabe refleksive praksisrum, hvori der kan arbejdes med autentiske og praksisnære problemer, men i tilknytning til uddannelsessystemet. Ideen er, at studerende/praktikere og lærere sammen kan arbejde på tværs af konkrete virksomheder og erfaringsbaggrunde og herved skabe muligheder for refleksion både i bredden og dybden.

Ideen med læringslaboratoriet er, at virksomheder og uddannelsesinstitutioner kan arbejde tættere sammen, så man kan lære af hinanden. Det betyder f.eks., at studerende kan få adgang til at afprøve forskellige projekter i en konkret praksis, og at virksomhedsrepræsentanter er med til at vurdere resultatet og foreslå nye læringsinitiativer. Det kan også betyde, at medarbejdere deltager i læringslaboratoriets aktiviteter, så læringslaboratoriet bliver en anledning til at få lov at reflektere lidt fjernere fra hverdagen, end udviklingsorganisationen tillader.

Både udviklingsorganisationen og læringslaboratoriet kan benytte sig af f.eks. simulering som en konkret læreskabelon. I et svensk forskningsprojekt har man således udviklet en processimulator, der gør det muligt for procesoperatører at eksperimentere med forløbet af forskellige driftstilstande. Simulatoren er ikke direkte forbundet med processtyringen, men den er placeret $i$ det tidligere kontrolrum på fabrikken. Her får gruppen af procesoperatører mulighed for i direkte tilslutning til deres arbejde med de virkelige driftssituationer at undersøge, hvad konsekvenserne kan være af forskellige alternative indgreb (Nilsson 1999). Planlægningsværktøjer for produktionsgrupper, der skal tilrettelægge den løbende produktion bliver på tilsvarende måde i stigende grad redskaber til gennem vekslinger mellem simuleringer og faktisk planlægning at lære sig mere om egne muligheder. I et videre perspektiv kan man tænke sig en hel ny klasse af værktøjer og hjælpemidler, der integrerer udførelsen af en opgave med muligheder for at eksperimentere og overvåge (monitére) egen indsats. Dette giver ikke mindst muligheder for at konstruere stadigt mere komplekse byggesten til den fortsatte videnskonstruktion.

Netværksetablering kan blive et andet vigtigt element i de nye læremiljøer. F.eks. i skolesammenhængen kan der arbejdes mere bevidst med at konstruere temporære 
fællesskaber, der tillader kursister at tilegne sig flere skabeloner for produktive læresituationer. Den amerikanske forsker Yasmin Kafai har eksempelvis etableret en interessant ramme omkring matematikundervisningen for 4. og 5. klasses børn ved at lade den laveste klasse udvikle computerspil om matematiske problemer, mens den ældre klasse, der allerede har gennemgået forløbet, fungerer som netværksforbundne tutorer for de yngre kammerater (Kafai 1995). Denne dobbelte løkke af konstruktion og med-konstruktion giver børnene en relevant og vedkommende opgave at arbejde sammen om. Cirkuleringen af roller giver dem ligeledes også muligheder for at spille ud med de arbejdsformer, de har lært i situationer, der i tiltagende grad kan komme til at ligne den praksis, de skal beherske.

Netværksetablering behøver ikke at have noget med informationsteknologi at gøre, men der er bestemt meget at lære sig i det frodige felt, som i de senere år har udviklet sig omkring informationsteknologien. Et andet interessant eksempel i denne sammenhæng er således etableringen af rollespilslignende mødesteder på nettet, hvor f.eks. lærere kan mødes i et virtuelt fællesskab, der af deltagerne konstrueres netop til at stimulere en form for faglig udveksling, der ikke kan etableres ansigt til ansigt. I en mere arbejdsnær sammenhæng har vi allerede nævnt, hvordan f.eks. opstillere inden for fjederindustrien mødes med mellemrum og ser video af hinandens opstillinger. I en tid, hvor stadig flere arbejder i medierige omgivelser, er det nærliggende at forestille sig, at denne form for netværksetablering kan få en opblomstring, når vi finder måder at forbinde os på uden at være fysisk til stede i samme rum.

Udviklingsorganisationen og læringslaboratoriet opfatter vi således som to læremiljøer, hvor det er muligt at arbejde med nye læreskabeloner. Det vil sige læreskabeloner, der har inkluderet 'samtidighedstænkning' i kraft af, at der arbejdes med autentiske og virkelighedsnære problemer på tværs af praksis og teori samt forskellige faglige fællesskaber. Simulering og netværksetablering er blot to eksempler på pædagogiske værktøjer, der kan fremme pendlingen mellem praksis og teori - udspil og overvejelse.

\section{Opsummering}

Vi har med afsæt i en kritik af industrisamfundets 'sekvenstænkning' og videnssamfundets 'samtidighedstænkning' samt forskning inden for læring peget på to konkrete læremiljøer som scenarier for udvikling af nye læreskabeloner, nemlig udviklingsorganisationen og læringslaboratoriet. Vores sammenfattende karakteristik af de nuværende udfordringer i måden at tænke læring er indeholdt $\mathrm{i}$ det overordnede skift fra 'sekvenstænkning' og vægtning af viden som noget, der kan bevares, til 'samtidighedstænkning' og vægt på viden, som noget, der til stadighed må konstrueres. Vi har peget på, at dette skift flytter læringsproblematikken såvel tættere på som længere fra praksis.

Læringsproblematikken flytter tættere på praksis, fordi vi i stigende grad håndterer udfordringer, der er nye og i stadig forandring, og derfor må se læring som en integreret del af kompetent udførelse af arbejdet. Når vi samtidig hævder, at læringsproblematikken også rykker længere væk fra praksis, skyldes det, at muligheden for at sammenfatte gode måder at handle på ikke længere kan finde sted som generelle metoder og fremgangsmåder (som f.eks. kan videregives i den traditionelle skolesammenhæng), men i stedet må forfølges ved, på distance, at reflektere over angrebsvinkler og 
perspektiver på praksis - der gennem den distancerede refleksion kan lede til fornyelser.

De udfordringer, som dette skift stiller til læreskabeloner og læremiljøer, rækker hele vejen rundt om læringstænkningen, fra vores detailforestillinger om de enkelte læresituationer og til vores måde at organisere og indplacere læremiljøer i samfundet. På mikro-niveauet har vi argumenteret for, at man skal rette fornyet opmærksomhed mod, hvordan den lærende får mulighed for at engagere sig i kontinuerlig veksling mellem handling og refleksion, udspil og overvejelse. Vi har påpeget betydningen af rum for læring, hvor den lærende er i kontrol med tiden og har adgang til et eget univers af genstande og redskaber, som kan aktivere tidligere erfaringer og viden i læresituationen.

Vi har desuden peget på betydningen af at se læring som deltagelse i sociale fællesskaber, og vi har forsøgt at vise, hvordan ikke blot læring, men også færdigheder og viden må forstås som noget, der tilhører fællesskabet snarere end den enkelte. Endelig har vi peget på, at det er i mødet med andre fagligheder, nye indsigter kan skabes. Betoningen af den kontinuerlige læring gør det relevant at bryde med den konventionelle forestilling om, at man først skal lære sig sin egen faglighed, før man lærer sig at indgå i relationer med andre professioner. Fælles for de forhold, vi har taget frem, er, at de alle i større eller mindre grad har spillet en rolle også for de læreprocesser, vi allerede kender, men at de på en helt anderledes måde må eksponeres, hvis vi skal stimulere de læringsbehov, vi ser foran os.

\section{Litteratur}

Alvesson M. (1995): Management of Knowledge-intensive Companies, Berlin, Walter de Gruyter.

Bauer M. \& Borg K. (1976, c. 1986): Den skjulte laereplan, København, Unge Pædagoger.

Binder T. (1995): Designing for Workplace Learning, i AI \& Society, vol. 9/3 1995.

Bourdieu P. (1990): The Logic of Practice, Cambridge, Polity Press.

Broady D. (1981): Den dolda lärorplan, Stockholm, Symposium.

Dewey J. (1916, c. 1966): Democracy and Education - An Introduction to the Philosophy of Education, New York, The Free Press.

Dreyfus H.L. \& Dreyfus S.E. (1991, eng. udg. 1986): Intuitiv ekspertise - den bristede drфm om tonkende maskiner, København, Munksgaard.

Ehn P. (1987): Work oriented Design of Computer Artifacts, Stockholm, Arbetslivscentrum.

Elkjær B. (1999): In search of a social learning theory, i M. Easterby-Smith; L. Araujo \& J. Burgoyne (eds.) Organizational Learning and the Learning Organisation - Developments in Theory and Practice, London, Sage.

Elkjær B. (2000): Knowledge Work and Organisational Learning, Working Paper no. 1., Copenhagen Business School, Department of Informatics.

Engelstad P.H. (1996): The Development Organization as Communicative Instrumentation, i S. Toulmin \& B. Gustavsen (eds.) Beyond Theory - Changing Organizations through Participation, Amsterdam, Philadelphia, John Benjamins Publishing Company.

Fischer G. (1999): Lifelong Learning - Changing Mindsets, i Proceedings of ICCE 99, 7th International Conference on Computers in Education on »New Human Abilities for the Networked Society«, Chiba, Japan. [http:// www.cs.colorado.edu/ gerhard/papers/icce9 9.pdf]

Garrison J. (1995): Deweyan Pragmatism and the Epistemology of Contemporary Social Constructivism, i American Educational Research Journal, no. 4, 1995. 
Hvenegaard H. \& Trolle H. (1996): Den larende organisation - Fra udbrandthed til udvikling, København, Arbejdsmiljøfondet.

Kafai Y.B. (1995): Minds in Play - Computer game design as a context for children's learning, Hillsdale, Lawrence Erlbaum Associates.

Kirschner P.A. (1999): Using Integrated Electronic Environments for Collaborative Teaching/Learning, Keynote address presented at EARLI conference in Gothenborg, Sweden.

Lave J. \& Wenger E. (1991): Situated Learning - Legitimate Peripheral Participation, Cambridge, Cambridge University Press.

Lave J. (1988): Cognition in Practice, Cambridge, Cambridge University Press.

McLuhan M. (1964, c. 1994): Understanding Media - The Extensions of Man, Cambridge, The MIT Press.

Meier F. (1998): Laering er indviklet i praksis! et speciale om laringsbegreber, uformelle laereprocesser og fjedervikling, Rapportserien nr. 63, Roskilde, Tek-Sam Forlaget.

Miller C.M. (1995): So can you build one? Learning through designing - connecting theory with hardware in engineering education, Massachusetts, Massachusetts Institute of Technology.

Nielsen K. \& Kvale S. (red.) (1999): Mesterlare - Laering som social praksis, København, Hans Reitzels Forlag.
Nilsson J. (1999): Operatörens blick, PhD-afhandling, Lund, Informatik (under udgivelse).

Orr J.E. (1996): Talking about machines - An ethnography of a modern job, Ithaca, ILR Press.

Perby M.L. (1995): Konsten att bemästra en process - om att förvalta yrkeskunnande, Hedemora, Gidlund.

Philips D.C. (1995): The Good, the Bad, and the Ugly - The Many Faces of Constructivism, i Educational Researcher, no. 7, 1995.

Rasmussen J. (1999): Mesterlære og den almene pædagogik, i K. Nielsen \& S. Kvale (red.) Mesterlare - Laring som social praksis, København, Hans Reitzels Forlag.

Reich R. (1991): The Work of Nations, New York, Vintage Books.

Schön D.A. (1983): The Reflective Practitioner - How Professionals Think in Action, New York, Basic Books.

Schön D.A. (1987): Educating the Reflective Practitioner - Toward a New Design for Teaching and Learning in the Professions, New York, Basic Books.

Wenger E. (1998): Communities of Practice Learning, Meaning, and Identity, Cambridge, Cambridge University Press.

Zuboff S. (1988): In The Age of the Smart Machine - The Future of Work and Power, New York, Heinemann.

Thomas Binder er forskningsleder ved The Interactive Institute i Malmö, Sverige Email: thomas.binder@interactiveinstitute.se

Bente Elkjær er lektor ved Institut for Informatik, Handelshøjskolen i København Email: elkjaer@cbs.dk 